\title{
Revalidatie bij relatief milde coronaklachten
}

\section{Bas Sorgdrager}

De meeste COVID-19-besmettingen gaan gepaard met milde klachten. Hoewel het medisch herstel doorgaans voorspoedig verloopt, houden veel mensen klachten van vermoeidheid en concentratieverlies. Precieze cijfers zijn niet bekend. De klachten kunnen een goede terugkeer in werk belemmeren. Met een relatief eenvoudig revalidatieprogramma is relevante verbetering te bereiken met als resultaat een duurzame werkhervatting. Aandacht voor de werkende met milde coronaklachten draagt bij aan optimale inzetbaarheid.

\section{Casus \\ De 38 jarige heer $\mathrm{R}$, in het dagelijks leven afdelings- manager in een academisch ziekenhuis en tevens regelmatig sporter, ontwikkelde in maart 2020 na een skivakantie in Oostenrijk een door het COVID- 19-virus veroorzaakte milde longontsteking (door huisarts vastgesteld). Een ziekenhuisopname bleek niet nodig. Het medische herstel verliep voorspoedig; drie weken na optreden van de eerste symptomen was hij klachtenvrij. Het conditionele herstel viel echter tegen en hij kon zich moeilijker concentreren; de werkhervatting verliep niet goed, blijkend uit erge vermoeidheid na een aantal uren werken. Hij bleek meer dan $5 \mathrm{~kg}$ te zijn afgevallen. Daarnaast was hij onzeker over zijn herstel en de prognose. Vragen zoals 'wat kan ik nu wel, wat moet ik wel of niet doen' waren de aanleiding om zich aan te melden voor het fit na COVID-programma dat in het revalidatiecentrum voor het eigen personeel was ontwikkeld. Bedrijfsart- sen van de arbodienst stelden de indicatie en regelden de verwijzing. De heer $\mathrm{R}$ stelde als doel een duurzame werkhervatting. Het multidisciplinair programma heeft aandacht voor conditieopbouw met bewaken van gezondheidsparameters, mentale begeleiding en leefstijladvies. De heer R evalueerde het traject als zeer positief; het gestelde doel was behaald.}

\section{Een fit na COVID-programma}

Het programma was aanvankelijk bedoeld voor het eigen personeel, maar is intussen ook voor anderen beschikbaar. De deelnemers zijn wel besmet geweest, hebben slechts relatief milde klachten ervaren en hebben niet in het ziekenhuis gelegen. De mensen ervaren belemmeringen in een adequate terugkeer in werk op het gebied van

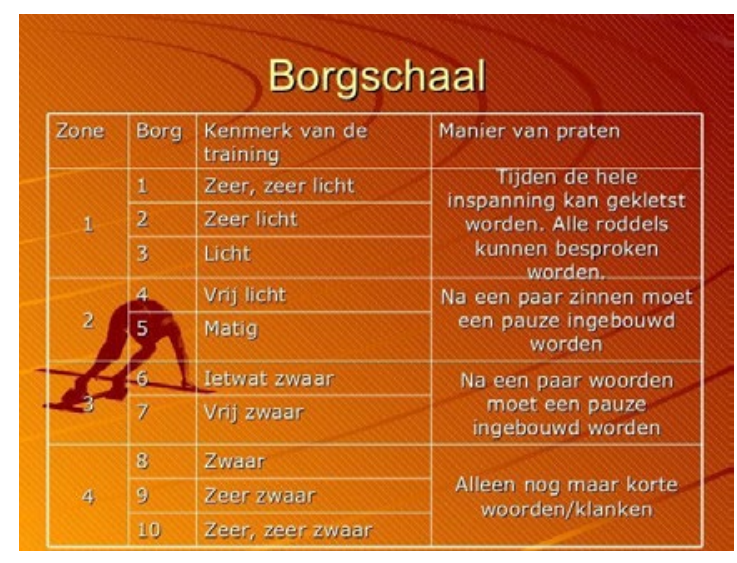

Figuur. Borgschaal, gebruikt in fysiotherapietrainingen

uithoudingsvermogen, kracht en overige leefstijlgerelateerde factoren. De klachten zijn niet complex genoeg voor een indicatie medisch specialistische revalidatie. Het programma kan derhalve niet worden gedeclareerd bij een zorgverzekeraar, maar is een re-integratievoorziening geïndiceerd door bedrijfsarts en gefinancierd door werkgever. Er is een contra-indicatie als er sociaal-emotionele factoren op de voorgrond staan. Voor deelname moet men tweemaal negatief zijn getest. Het programma duurt acht weken en wordt gecoördineerd door een beweeg- en leefstijladviseur, die ook een eindrapportage opstelt voor verwijzer en deelnemer.

De start is een zesminutenwandeltest met saturatiemeting. Het traject omvat beeldbellen met voorlichting en educatie, ook om gestelde doelen continu te evalueren, en fysieke trainingen (duur- en functionele krachttraining). De begeleiders houden het optreden van klachten bij, ze meten zuurstofsaturatie- en hartfrequentie en gebruiken de Borgschaal voor kortademigheid en vermoeidheid (zie figuur). De effectiviteit van het programma wordt geëvalueerd met een vragenlijst en een herhaling van de zesminutenwandeltest. De wandeltest verbetert gemiddeld $10 \%$ bij de deelnemers. Voor een wetenschappelijke evaluatie is het aantal deelnemers echter te klein en er is geen controlegroep gevolgd.

Bas Sorgdrager is klinisch arbeidsgeneeskundige, onder meer werkzaam voor Team Arbeid van de BV Beatrixoord, Centrum voor Revalidatie UMCG te Haren 